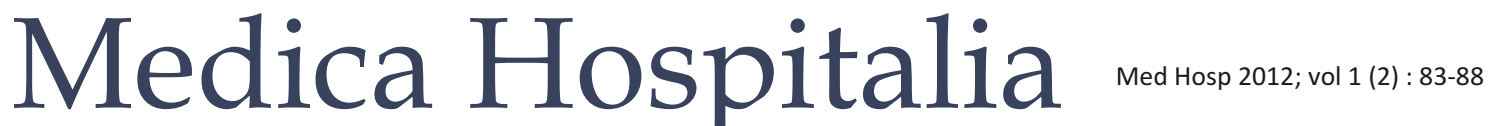

Original Article

\section{Penurunan Nilai Ambang Dengar \\ Penderita Keganasan Kepala Leher yang Mendapat Kemoterapi Cisplatin dan Radiasi Eksternal}

\author{
Ferri Daniel, Wiratno, Muyassaroh \\ Bagian Ilmu Kesehatan THT-KL Fakultas Kedokteran Universitas Diponegoro/RSUP Dr. Kariadi Semarang
}

\begin{abstract}
Abstrak
Latar belakang : Cisplatin dan radiasi eksternal tunggal maupun kombinasi, memproduksi radikal bebas yang bisa menyebabkan kerusakan sel rambut organ korti dengan akibat penurunan nilai ambang dengar. Tujuan penelitian ini adalah membuktikan bahwa penurunan nilai ambang dengar pada kelompok penderita keganasan kepala leher (KKL) yang mendapatkan cisplatin dan radiasi eksternal lebih besar dibandingkan kelompok yang hanya mendapat cisplatin saja.

Metode : Penelitian randomized controlled trial pre-post test group design pada KKL selama 3 bulan. Subyek yang memenuhi kriteria inklusi di klinik THT-KL RSUP Dr. Kariadi Semarang dibagi dua kelompok, yaitu cisplatin 2 seri+2000cGy radiasi eksternal (perlakuan) dan cisplatin (kontrol). Data meliputi nilai ambang hantaran tulang audiogram nada murni kedua kelompok. Analisis data dengan chi-square dan independent-sample t-test.

Hasil : Terdapat 29 subyek terdiri dari 14 subyek kelompok perlakuan dan 15 subyek kelompok kontrol. Rerata nilai ambang kedua kelompok tidak berbeda bermakna (telinga kanan $p=0,34$; telinga kiri $p=0,26)$. Penurunan nilai ambang dengar hantaran tulang kelompok perlakuan lebih besar dibanding kelompok kontrol dengan perbedaan selisih nilai ambang hantaran tulang bermakna (telinga kanan $p=0,02$; telinga kiri $p=0,01$ ).

Simpulan : Penurunan nilai ambang hantaran tulang audiogram nada murni penderita KKL dengan terapi cisplatin dan radiasi eksternal terbukti lebih besar dibanding kelompok dengan terapi cisplatin saja.
\end{abstract}

Kata kunci : Kanker kepala dan leher, cisplatin dan radiasi eksternal, hantaran tulang.

\section{The Decrease of Bone Conduction Threshold of Head and Neck Cancer Patients Treated by Cisplatin and External Radiation}

\begin{abstract}
Background : Cisplatin and external radiation either singular or combined, produce free radicals that can cause damage to hair cell of organ corti with the decrease of bone conduction threshold on pure tone audiogram. The aim is to prove that the decrease of bone conduction threshold pure tone audiogram in the group of head and neck cancer patients who received cisplatin and external radiation is greater than the group with cisplatin only.

Methods : A randomized controlled trial pre-post test group design reseach. Subjects that met the inclution criteria at ENTH\&N clinic and ward of Kariadi Hospital, Semarang divided into two groups; cisplatin + 2000 cGy external radiation (studied group) and cisplatin only (control group). The data include the bone conduction threshold pure tone audiometry of two original groups. The data were analized with Chi-square test and Independent-samplettest.

Results : Twenty-nine subjects were divided into 2 groups; 14 subjects of the study group and 15 subjects of control group. The average of bone conduction threshold of the study group and the control group was not significantly different, (right ear $p=0.34$; left ear $p=0.26$ ). The decrease of bone conduction threshold in the study group is higher than that of the control group with significant differences in the bone conduction threshold (right ear $p=0.02$; left ear $p=0.01$ ).

Conclusion : The decrease of bone conduction threshold pure tone audiogram in head and neck cancer patients who received cisplatin and external radiation therapy proved greater than that of the group with cisplatin only.
\end{abstract}

Keywords : Head and neck cancer, cisplatin and external radiation, bone conduction 


\section{PENDAHULUAN}

Keganasan kepala dan leher (KKL) sering dijumpai di Indonesia. ${ }^{1,2}$ Penatalaksanaan keganasan kepala dan leher meliputi operasi, radiasi, kemoterapi atau kombinasi. ${ }^{3,4}$ Kemoterapi paling banyak digunakan adalah cisplatin-5FU. Di RSUP Dr. Kariadi cisplatin dikombinasikan dengan paklitaksel. Cisplatin terbukti berkhasiat memperkecil ukuran tumor, mengurangi kemungkinan terjadinya mikrometastasis serta meningkatkan sensitivitas tumor terhadap radiasi. Efek cisplatin adalah sitotoksik, radiosensitizer terhadap tumor dan ototoksik. ${ }^{4,5,6}$ Ototoksisitas cisplatin terjadi karena peningkatan produksi radikal bebas (ROS) di dalam koklea sehingga memacu terjadinya apoptosis pada sel-sel di koklea yang menyebabkan rusaknya selsel rambut koklea (outer dan inner hair cells), stria vaskularis, dan saraf di ganglion spiralis. Hal ini menyebabkan gangguan pendengaran/penurunan nilai ambang dengar. ${ }^{4,7} 8$ Gangguan pendengaran ditemukan pada daerah frekuensi tinggi, meskipun bisa ke daerah frekuensi rendah, bilateral, dan irreversible. Insidensi bervariasi antara $50 \%$ hingga $60 \%$ dan meningkat pada dosis kumulatif (>400 mg). Efek ototoksik sering muncul 2-7 hari setelah kemoterapi. ${ }^{7,9}$
Radiasi diberikan juga pada KKL. Radiasi bersifat nonselektif yaitu dapat merusak sel normal dan sel kanker. Kerusakan sel dapat terjadi karena efek langsung /tidak langsung. Efek langsung ionisasi sinar elektromagnetik dan efek tidak langsung karena adanya radikal bebas berlebihan akibat radiasi air $(\mathrm{H} 2 \mathrm{O})$ terurai menjadi radikal bebas. Radikal bebas merusak DNA dan struktur sel sehingga sel mengalami apoptosis, termasuk sel sel rambut koklea, akibatnya penderita mengalami penurunan nilai ambang pendengaran. ${ }^{5,6}$ Sataloff meneliti 22 penderita KNF yang menjalani radiasi eksternal, terdapat hubungan bermakna antara penurunan nilai ambang hantaran tulang (NA HT) mulai minggu kedua radioterapi dan meningkat pada minggu keenam dari $10 \%$ menjadi $31,4 \% .{ }^{10}$ Penelitian Wang dkk, 2004 bahwa penurunan NA HT setelah pemberian radiasi awalnya kemungkinan bersifat sementara tetapi pengaruh radiasi pada pendengaran cenderung kronik dan progresif. $^{11}$

Penelitian mengenai penurunan NA HT yang mendapat kemoterapi cisplatin dan radiasi eksternal pada penderita KKL di RSUP Dr. Kariadi Semarang belum pernah dilaporkan. Tujuan penelitian ini adalah membandingkan NA BC audiogram nada murni penderita KKL yang mendapatkan cisplatin dan eksternal

\begin{tabular}{|c|c|c|c|c|}
\hline \multicolumn{5}{|c|}{$\begin{array}{l}\text { TABEL } 1 \\
\text { Karakteristik sampel penelitian }\end{array}$} \\
\hline Variabel & $\begin{array}{l}\text { Perlakuan (\%) } \\
\quad(n=14)\end{array}$ & $\begin{array}{c}\text { Kontrol (\%) } \\
(n=15)\end{array}$ & $\begin{array}{c}\text { Total (\%) } \\
(n=29)\end{array}$ & $p$ \\
\hline \multicolumn{5}{|l|}{ Kelompok usia(tahun) } \\
\hline $20-29$ & $0(0)$ & $1(3,4)$ & $1(3,4)$ & 0,087 \\
\hline $30-39$ & $4(13,8)$ & $2(6,9)$ & $6(20,7)$ & \\
\hline $40-49$ & $6(20,7)$ & $3(10,3)$ & $9(31,0)$ & \\
\hline $50-59$ & $4(13,8)$ & $6(20,7)$ & $10(34,5)$ & \\
\hline$\geq 60$ & $0(0)$ & $3(10,3)$ & $3(10,3)$ & \\
\hline \multicolumn{5}{|l|}{ Jenis kelamin } \\
\hline Laki-laki & $12(41,4)$ & $10(34,5)$ & $22(75,9)$ & 0,019 \\
\hline Perempuan & $2(6,9)$ & $5(17,2)$ & $7(24,1)$ & \\
\hline \multicolumn{5}{|l|}{ Jenis tumor } \\
\hline Karsinoma nasofaring & $12(41,4)$ & $12(41,4)$ & $24(82,8)$ & 0,360 \\
\hline Kavum nasi & $1(3,4)$ & $1(3,4)$ & $2(6,9)$ & \\
\hline Karsinoma tonsil & $0(0)$ & $1(3,4)$ & $1(3,4)$ & \\
\hline Karsinoma laring & $1(3,4)$ & $0(0)$ & $1(3,4)$ & \\
\hline Karsinoma palatum & $0(0)$ & $1(3,4)$ & $1(3,4)$ & \\
\hline \multicolumn{5}{|l|}{ Stadium tumor } \\
\hline Awal & $2(6,9)$ & $4(13,8)$ & $6(20,7)$ & 0,108 \\
\hline Lanjut & $12(41,4)$ & $11(37,9)$ & $23(79,3)$ & \\
\hline
\end{tabular}

Chi-square, signifikan $p<0,05$ 
radiasi (ER) dengan yang hanya mendapat kemoterapi cisplatin saja.

\section{METODE}

Penelitian pre-post test design pada penderita KKL di RSUP Dr. Kariadi Semarang selama bulan Nopember 2011-Januari 2012 dengan kriteria inklusi penderita KKL dengan kemoterapi cisplatin dengan/tanpa ER, KKL stadium II-IV, usia >15 tahun, hasil laboratorium darah dalam batas normal, Karnofsky performance status scale (status Karnofsky) $\geq 60 \%$ dan bersedia ikut dalam penelitian sampai selesai dengan menanda tangani informed consent. Kriteria eksklusi adalah penderita dengan penyakit telinga kronik, DM, hipertensi, hiperkolesterolemia, riwayat terpapar bising, pernah mendapat radiasi di daerah kepala dan leher sebelumnya dan NAHT awal sebelum kemoterapi ER $\geq 60 \mathrm{~dB}$ serta penderita pernah mendapat terapi obat-obat yang bersifat ototoksik sebelumnya, misalnya antibiotika golongan aminoglikosida, diuretik, dan sitostatika lain (Vinkristin, Bleomycin). Besar sampel minimal masing masing kelompok 14, ditentukan dengan tingkat kemaknaan 0,05 dengan beda derajat kurang dengar 15dB. Pengelompokan sampel dilakukan secara acak blok, besar blok ditentukan empat penderita.

\begin{tabular}{|c|c|c|c|}
\hline \multicolumn{4}{|c|}{$\begin{array}{l}\text { HaBAE } 2 \\
\text { sesudah cisplatin II + radiasi eksterna dan } \\
\text { cisplatin II saja }\end{array}$} \\
\hline \multirow[t]{2}{*}{ Kelompok } & \multicolumn{2}{|c|}{ Pendengaran } & \multirow[t]{2}{*}{$p$} \\
\hline & $\begin{array}{l}\text { Menurun } \\
(\%)\end{array}$ & $\begin{array}{c}\text { Tetap/Membaik } \\
(\%)\end{array}$ & \\
\hline \multicolumn{4}{|l|}{ Telinga kanan } \\
\hline Perlakuan & $14(48,3)$ & $0(0)$ & 0,224 \\
\hline Kontrol & $12(41,4)$ & $3(10,3)$ & \\
\hline \multicolumn{4}{|l|}{ Telinga kiri } \\
\hline Perlakuan & $14(48,3)$ & $0(0)$ & 0,042 \\
\hline Kontrol & $10(34,5)$ & $5(17,2)$ & \\
\hline
\end{tabular}

Pemeriksaan audiometri dilakukan sebelum pemberian kemoterapi/kemoradiasi dan sesudah pemberian cisplatin seri ke-2 + ER 2000cGy (kelompok kasus), sesudah pemberian cisplatin seri-2 (kelompok kontrol). Dinilai NA HT yang terjadi pada kedua kelompok selanjutnya dianalisis hasil audiometri NA HT pre dan post cisplatin dan ER. Analisis data dengan uji chi square dan Uji beda NA HT setelah Cisplatin seri ke-2 dan selisih NA HT sebelum dan setelah Cisplatin seri ke-2 antara kedua kelompok, dianalisis dengan uji Independent-sample $t$ test. Ethical clearance disetujui Komite Etik Penelitian Kedokteran dan Kesehatan FK Undip/RSUP Dr. Kariadi Semarang

\section{HASIL}

Terdapat 29 subyek terdiri dari 14 subyek kelompok perlakuan dan 15 subyek kelompok kontrol. Rerata nilai ambang kedua kelompok tidak berbeda bermakna (telinga kanan $p=0,34$; telinga kiri $p=0,26$ ). Penurunan nilai ambang dengar hantaran tulang kelompok perlakuan lebih besar dibanding kelompok kontrol dengan perbedaan selisih nilai ambang hantaran tulang bermakna (telinga kanan $p=0,02$; telinga kiri $p=0,01$ ).

\section{PEMBAHASAN}

Hasil penelitian menunjukkan bahwa rerata usia pasien KKL 46,5 tahun, dengan usia termuda 20 tahun dan tertua 60 tahun. Hasil ini sesuai dengan penelitian di RSUP Dr. Kariadi Semarang (2001-2005) yang menyatakan bahwa prevalensi keganasan paling banyak pada kelompok usia lebih dari 40 tahun dan insidennya meningkat bersamaan dengan bertambahnya usia.s

Karakteristik penderita menurut jenis kelamin laki-laki lebih banyak $22(75,86 \%)$ daripada perempuan $7(24,14 \%)$ dengan perbandingan $3: 1$. Hasil ini sesuai dengan Munir di RSCM Jakarta yang menyatakan bahwa prevalensi laki-laki lebih besar daripada perempuan untuk terkena KKL. Hal yang menyebabkan jumlah penderita laki-laki lebih banyak daripada perempuan karena adanya faktor lingkungan yang berhubungan dengan paparan alkohol, polusi, dan rokok. ${ }^{1,12}$

\section{TABEL 3}

Hasil NAHT BC telinga kanan-kiri penderita KKL sesudah cisplatin II + radiasi eksterna dan cisplatin II saja

\begin{tabular}{|cccc} 
& Kelompok & Kontrol (dB) & $\boldsymbol{p}^{*}$ \\
& $\begin{array}{c}\text { Perlakuan (dB) } \\
\text { Rerata (SB) }\end{array}$ & Rerata (SB) & 0,027 \\
\hline$\Delta$ NA telinga kanan & $9,29(4,445)$ & $4,44(6,544)$ & 0,011 \\
\hline NA telinga kanan & $10,14(4,074)$ & $4,00(7,368)$ & 0 \\
\hline
\end{tabular}


Distribusi jenis keganasan menunjukkan bahwa jenis keganasan terbanyak adalah karsinoma nasofaring $24(82,759 \%)$ kasus yang merupakan keganasan tersering di daerah kepala dan leher. ${ }^{1,2}$

Stadium penyakit yang ditemukan pada penelitian terbanyak adalah stadium lanjut. Penderita datang berobat biasanya bila sudah stadium lanjut dimana tumor sudah meluas ke jaringan sekitar atau kelenjar limfe leher serta sangat mengganggu aktivitasnya sehari-hari. Hal ini disebabkan karena kurangnya pengetahuan masyarakat terhadap KKL terutama gejala dini, selain itu keadaan sosial ekonomi yang rendah. ${ }^{1}$

Pengaruh ototoksisitas cisplatin dapat timbul karena adanya kerusakan daerah koklea, terutama di selsel rambut putaran basal organ corti, sel-sel di ganglion spiralis, dan stria vaskularis. Cisplatin dapat menyebabkan produksi ROS meningkat di dalam tubuh. Akumulasi ROS akan melepaskan sitokrom-c dari mitokondria melalui aktivasi c-Jun-N-terminal kinase (JNK) dan p38MAPK. Sitokrom-c kemudian akan mengaktivasi caspase-8, -9, dan -3 (apoptosis jalur intrinsik), sehingga menyebabkan terjadinya apoptosis pada sel, dalam hal ini sel-sel di koklea. ${ }^{13,14}$

Ototoksisitas akibat cisplatin berkaitan dengan dosis yang diberikan pada penderita. Cisplatin dosis rendah akan menyebabkan kerusakan awal di stereosilia sel rambut di dalam organ Corti. Kerusakan yang terjadi ini dapat bersifat sementara maupun permanen. ${ }^{13,14}$ Cisplatin dosis tinggi dengan siklus pemberian yang meningkat, atau pada pengulangan terapi untuk siklus berikutnya akan membuat efek akumulasi dari cisplatin. ${ }^{15,16}$ Brock et al melaporkan $64 \%$ pasien pediatrik mengalami ototoksisitas cisplatin hanya dengan dosis kumulatif cisplatin 200 mg. ${ }^{17}$

Cisplatin pada penelitian ini diberikan dengan dosis $80 \mathrm{mg} / \mathrm{m}^{2}$ untuk satu seri kemoterapi. Setelah dua seri kemoterapi rata-rata sampel telah mendapatkan dosis kumulatif cisplatin sebanyak 200-250 mg.

Penurunan nilai ambang hantaran tulang akibat radiasi telah lama diketahui merupakan efek samping yang penting. Penurunan pendengaran hantaran tulang dengan onset awal terjadi selama atau segera setelah radiasi diberikan, biasanya terjadi beberapa bulan atau tahun setelah diberikan radiasi. Beratnya kejadian kurang pendengaran tersebut berhubungan dengan dosis radiasi yang digunakan. ${ }^{12}$ Apoptosis pada sel rambut koklea ditemukaan terutama terjadi pada 72 jam paska radiasi dan tergantung dosis paparannya, dengan kematian sel apoptosis lebih banyak terjadi pada dosis radiasi 20 Gy daripada $5 \mathrm{~Gy} .{ }^{18}$

Proses apoptosis terkait gen p53 berperan dalam kematian sel koklear akibat radiasi, namun bukan mekanisme satu-satunya yang terlibat, sejumlah mekanisme yang berbeda juga terlibat dalam proses ototoksisitas akibat radiasi.
Pertama, kematian nekrotik sel terutama pada dosis radiasi tinggi. Hal ini merupakan bentuk pasif dari kematian sel yang tidak mencakup aktivasi program selular spesifik. ROS dapat berkontribusi terhadap proses kematian dengan menyebabkan terjadinya lipid peroksidasi pada sel membran. ${ }^{18}$ Kedua, mekanisme tidak tergantung gen $\mathrm{p53}$, hal ini karena apoptosis yang diinduksi oleh radiasi LET tinggi, tidak dipengaruhi oleh status gen p53. Radiasi ionisasi dapat menginduksi caspase-dependent tetapi terjadi kematian sel tergantung p53 pada Drosophilia. Hal ini mungkin terjadi sebagai akibat dari pembentukan ceramide, di mana ceramide telah diketahui memicu aktivasi caspase selama proses apoptosis yang diinduksi oleh gamma pada sel glioma manusia yang memiliki p53 yang telah berkurang fungsinya. ${ }^{18}$

Ketiga, mekanisme kematian sel terprogram caspase-independent. Protease non-caspase seperti cathepsins, calpains, dan granzymes juga terlibat, menyebabkan proses pensinyalan intraseluler yang dapat menyebabkan terbentuknya sel yang mirip mengalami apoptotik atau nekrotik pada program kematian sel. Leupeptin (inhibitor calpain) dapat melindungi sel-sel telinga dalam dari ototoksisitas aminoglikosida. ${ }^{18}$

Pasien pada kelompok kemoradiasi mengalami kerusakan hantaran tulang yang lebih parah dibandingkan pasien pada kelompok kemoterapi saja. Pada penelitian terhadap hewan dan patologi, sel silia luar pada koklea menderita kerusakan yang berat setelah diberikan radioterapi, dan perubahan yang mirip dapat ditemukan pada efek ototoksisitas cisplatin. ${ }^{19}$

Low dkk menunjukkan adanya pembentukan ROS intraseluler terkait dengan dosis radiasi pada satu jam pertama setelah radiasi dan menjadi faktor pencetus penting dalam proses apoptosis akibat radiasi pada sel OC-k3 telinga dalam. Pada studi eksperimen hewan mengenai ototoksisitas aminoglikosida, kematian sel rambut luar di dalam Organ Corti diamati untuk dinilai gradient dari dasar ke apeksnya kemudian dapat dikurangi dengan menggunakan agen antioksidan. Hal ini berdampak pada sel rambut luar di dalam basal coil (yang berespon terhadap suara berfrekuensi tinggi) yang memiliki kadar glutathione yang lebih rendah daripada yang ada di regio apikal (berespon terhadap suara berfrekuensi rendah) dan oleh karena memiliki kapasitas antioksidan yang lebih rendah. ${ }^{20}$

Berdasarkan penurunan NA HT kedua kelompok penelitian mengalami penurunan nilai ambang baik telinga kanan maupun kiri, dan jumlah subyek dari kelompok perlakuan lebih banyak daripada kelompok kontrol dengan perbedaan yang bermakna $p=0,04$ (telinga kiri) dan $p=0,22$ (telinga kanan). Penurunan NA HT dikatakan signifikan jika menunjukkan perbedaan $10 \mathrm{~dB}$ dari NA HT sebelumnya ${ }^{49}$ dan pada penelitian ini terdapat perbedaan rerata selisih NA HT yang bermakna 
antara kelompok perlakuan dan kontrol $(p=0,027)$ pada telinga kanan dan $(p=0,011)$ pada telinga kiri.

Fungsi pendengaran ditentukan oleh sistem konduktif dan sensorineural pada telinga. ${ }^{21}$ Kelompok kontrol tidak dilakukan pemeriksaan audiometri nada murni yang ketiga karena rerata dan uji statistik nilai ambang kelompok perlakuan dan kelompok kontrol yang dapat dinilai keduanya sesudah cisplatin II dan membuktikan hasil penelitian Sataloff bahwa terdapat hubungan yang bermakna antara penurunan nilai ambang hantaran tulang mulai minggu kedua radioterapi.

Penelitian ini hanya menilai fungsi hantaran tulang dari pendengaran. Berdasarkan NA hantaran tulang setelah kemoterapi II, didapatkan kurang lebih hanya $30 \%$ penderita yang mengalami penurunan pendengaran setelah kemoterapi II, dimana jumlah kelompok perlakuan lebih banyak dibanding kontrol. Kelompok perlakuan mengalami penurunan NA hantaran tulang lebih berat dibanding kelompok kontrol dengan perbedaan bermakna didapat pada telinga kiri $p=0,01$ rerata NA hantaran tulang kelompok perlakuan masih lebih baik dibanding control, tetapi tidak didapatkan perbedaan yang bermakna diantara kedua kelompok $p=0,18$ pada telinga kanan dan $p=0,33$ pada telinga kiri.

Hasil ini sesuai dengan penelitian De Jongh et al melaporkan $42 \%$ dari 400 pasien yang mendapat cisplatin dosis tinggi $\left(70-85 \mathrm{mg} / \mathrm{m}^{2}\right.$, median dosis kumulatif $420 \mathrm{mg}$ ) mengalami gejala ototoksik berat. ${ }^{22}$ Bokemeyer $e t$ al melaporkan bahwa insiden ototoksik akan meningkat drastis jika dosis kumulatif total cisplatin mencapai $400 \mathrm{mg}^{23}$ Low et al melaporkan bahwa penderita karsinoma nasofaring yang menerima kemoterapi cisplatin dan radioterapi mengalami penurunan NA HT yang lebih berat disbanding penderita yang hanya mendapat radioterapi saja, terutama pada frekuensi tinggi. ${ }^{19}$

Penurunan NA HT setelah pemberian cisplatin pada umumnya bersifat bilateral, simetris, dimulai dari frekuensi tinggi, dan ireversibel dimana sekresi pada ginjal masih dapat terdeteksi hingga 4 bulan setelah pemberian cisplatin. ${ }^{7,24} \mathrm{KP}$ unilateral jarang terjadi, pada umumnya disebabkan karena lokasi tumor dan riwayat operasi atau radioterapi sebelumnya pada sisi telinga tersebut. ${ }^{19}$ Hasil penelitian ini didapatkan bahwa selisih NA HT telinga kanan dan telinga kiri berbeda bermakna diantara kedua kelompok.

Rerata NA HT yang tidak bermakna diantara kedua kelompok kemungkinan dipengaruhi oleh faktorfaktor berikut, yaitu keadaan umum pasien pada saat pemeriksaan, sensitivitas masing-masing individu terhadap cisplatin, ketaatan pasien dalam minum vitamin yang diberikan, dan pengaruh obat-obat lain yang diminum oleh pasien. Keadaan umum pasien saat pemeriksaan audiometri sangat berpengaruh terhadap hasil audiometri. Biasanya pasien yang mendapat obatobat kemoterapi berada dalam kondisi sakit, sehingga menyulitkan pemeriksaan audiometri yang membutuhkan perhatian penuh dan respon pasien.

Penurunan NA HT pada kedua kelompok sampel penelitian ini diperkirakan akan terus menurun seiring waktu dengan dilanjutkannya kemoterapi cisplatin dan radiasi eksterna sampai dosis optimal dan onset terjadinya penurunan nilai ambang hantaran tulang akibat reaksi lambat radioterapi. Keterbatasan penelitian ini dilakukan pada penderita dengan pemberian terapi belum penuh (cisplatin baru sampai 2 seri dari 6-8 seri seharusnya, radiasi eksternal 2000 cGy dari 6000 cGy) dan belum seluruh faktor-faktor yang berpengaruh ditelaah dengan cermat dan mendalam.

\section{SIMPULAN}

Penurunan nilai ambang hantaran tulang audiogram nada murni penderita KKL yang mendapat cisplatin dan radiasi eksternal lebih besar dibandingkan dengan penderita yang hanya mendapat cisplatin saja. Perlu dilakukan penelitian lebih lanjut pada penderita mendapat terapi cisplatin dan radiasi eksternal secara penuh, dan mempertimbangkan faktor-faktor berpengaruh termasuk faktor resiko secara lebih mendalam.

\section{DAFTAR PUSTAKA}

1. Bernardus JJ. Pengaruh polyphenols teh hijau terhadap kapasitas produksi IFN-y oleh sel mononuclear darah tepi akibat radioterapi pada penderita karsinoma nasofaring (tesis). Semarang. FK Undip, 2008. (diunduh : 25 Januari 2011). http://eprints.undip.ac.id/17979/1/pdf

2. Munir M. Keganasan dibidang telinga hidung tenggorok. Dalam : Soepardi EA, Iskandar N, Bashiruddin J, Restuti RD, eds. Buku Ajar Ilmu Kesehatan Telinga, Hidung, Tenggorok dan Kepala Leher, edisi ke enam .Jakarta : Balai Penerbit FKUI; 2007 : 162-73.

3. Wiliyanto O. Insidensi kanker kepala dan leher berdasarkan diagnosis patologi anatomi di RSUP Dr. Kariadi Semarang periode 1 Januari-31 Desember 2005 [artikel penelitian]. Semarang: FK Undip; 2006. Belum dipublikasikan

4. Brockstein BE, Vokes EE. Principles of chemotherapy in the management of head and neck cancer. In : Bailey BJ, Calhoun $\mathrm{KH}$, eds. Head and Neck Surgery - Otolaryngology. $4^{\text {th }}$ ed. Philadelphia: Lippincot-William \& Wilkins; 2006 :1428-41.

5. Droge W. Free radicals in the physiological control of cell function. Physiol Rev 2002; (82) : 47-85.

6. Johnson S, O'Dwyer P. Cisplatin and its analogues. In : DeVita V, Hellman S, Rosenberg S, eds. Cancer Principles and Practice of Oncology. $7^{\text {th }}$ ed. Philadelphia: Lippincott ; 2005:344-54.

7. Riggs LC. Ototoxicity. In : Bailey BJ, ed. Head \& Neck Surgery Otolaryngology. $2^{\text {nd }}$ ed. Philadelphia: Lippincot Raven; 1998: 2165-8.

8. Rybak LP, Toullitas JS, Campbell. Ototoxicity. In: Van de Water TR, Staecker H, eds. Otolaryngology Basic Science and Clinical Review. New York: Thieme; 2006:129-36

9. Bhandare N, Jackson A, Eisbruch A, Pan CC, Flickinger JC, Antonelli $\mathrm{P}$, et al. Radiation therapy and hearing loss. Int. J. 
Radiation Oncology Biol. Phys 2010; 76:50-7.

10. Satalof RT. Effect of cranial irradiation on hearing acuity: a review of the literature. Am JOtol 1994; 15:669-93

11. Wang LF. Along term study on hearing status in patient with nasopharyngeal carcinoma after radiotherapy. J Laryngol Otol. 2004; 25: 168-73.

12. Nurmasari S, Samiadi D, Purwanto B. Pengaruh radioterapi eksternal terhadap fungsi sel rambut luar koklea penderita karsinoma nasofaring. Dalam MKB, (42), 2, Bandung; 2010.

13. Gratton MA, Smyth BJ. Ototoxicity of Platinum Compunds. In: Roland, Rutko, eds. Ototoxicity. New York: BC Decker, Inc; 2004: 60-75.

14. Barabas K, Milner R, Lurie D, Adin C. Cisplatin: a review of toxicities and therapeutic applications. Vet $\mathcal{E}$ Comp Oncol. 2008; (6), 1:1-18.

15. Rybak, L.P. Mechanisms of cisplatin ototoxicity and progress in otoprotection. Curr Opin Otolaryngol Head Neck Surg. 2007; 15: 364-9.

16. Hitchcock YJ, Tward JD. Relative contribution of radiation and cisplatin-based chemotherapy to SNHL in head and neck cancer patients. Int. J. Radiation Oncology Biol, Phys, 2009 ; (73); 779-788.

17. Brock PR, Bellman SC, Yeomans EC. Cisplatin ototoxicity in children: a practical grading system. Med Pediatr Oncol. 1991; 19: 295-300.
18. Low WK, Tan GK, Chua WC, Sun L, Wang DY. $12^{\text {th }}$ Yahya cohen memorial lecture - the cellular and molecular basis of radiation-induced sensori-neural hearing loss. Ann Acad Med Singapore. 2009; 38: 91-4.

19. Low WK, Toh ST, Wee J, TohST, Stephanie MC, Chong F, Wang DY. Sensorineural hearing loss after radiotherapy and chemoradiotherapy: a single, blinded, randomized study. J Clin Oncol 2006; 24: 1904-09

20. Seidman MD, Vivek P. Intratympanic treatment of hearing loss with novel and traditional agents. Otolaryngol Clin North Am 2004; 37: 973-90.

21. Rademaker JM. Relationship between cisplatin administration and the development of ototoxicity. J Clin Onc. 2006 : (24), 6 : 918-24.

22. De Jongh FE, van Veen RN, Veltman SJ. Weekly high-dose cisplatin is a feasible treatment option: analysis on prognostic factors for toxicity in 400 patients. Br J Cancer. 2003; 88: 1199-206.

23. Bokemeyer C,Berger CC,Hartmaan JT. Analysis of risk factors for cisplatin induced ototoxicity in patients with testicular cancer. Br J Cancer. 1998; 77: 1355-62

24. Ekborn A. Cisplatin induced ototoxicity, pharmacokinetics, prediction and prevention. Stockholm: Department of Otolaryngology and Head \& Neck Surgery Karolinska Hospital;2003;13-16. 